\title{
Respon Mahasiswa terhadap Penggunaan Modul Berbasis Guided Inquiry pada Matakuliah Teknik dan Manajemen Laboratorium Biologi
}

\author{
Azza Nuzullah Putri ${ }^{1}$, Erda Muhartati ${ }^{2}$ \\ ${ }^{1,2}$ Program Studi Pendidikan Biologi, FKIP Universitas Maritim Raja Ali Haji, Tanjungpinang, Indonesia
}

Pengiriman: 30 Oktober 2017; Diterima: 2 Maret 2018; Publikasi: Maret 2018

\begin{abstract}
This research aims to determine the practicality of the module through student response to a guided inquiry-based module that has been developed to be used in the study of technical courses and management of biological laboratories. This research is a research and development with the development model Hannafin and Peck covering the stage: need assess, design, and development/I mplementation where each phase is conducted evaluation and revision. The Data obtained includes the results of practicality through student response to the developed modules. The instrument used is a student response poll. The response is a very positive response from all respondents (students). On all aspects of the get very practical category with an average percentage of $93 \%$ to be used in technical course and management of biological laboratories by students.
\end{abstract}

Keywords: module, guided inquiry, practicality,

\begin{abstract}
ABSTRAK: Penelitian ini bertujuan untuk mengetahui praktikalitas modul melalui respon mahasiswa terhadap modul berbasis guided inquiry yang telah dikembangkan untuk dapat digunakan dalam pembelajaran pada matakuliah teknik dan manajemen laboratorium biologi. Penelitian ini merupakan penelitian pengembangan (research and development) dengan menggunakan model pengembangan Hannafin dan Peck yang meliputi tahap: need assess, design, and development/i mplementation dimana pada tiap tahapnya dilakukan evaluasi dan revisi. Data yang didapatkan meliputi hasil praktikalitas melalui respon mahasiswa terhadap modul yang dikembangkan. Instrumen yang digunakan yaitu berupa lembar angket respon mahasiswa. Berdasarkan angket respon didapatkan respon yang sangat positif dari seluruh responden (mahasiswa). Pada seluruh aspek di dapatkan kategori sangat praktis dengan rata-rata persentase 93\% untuk dapat digunakan pada matakuliah teknik dan manajemen laboratorium biologi oleh mahasiswa.
\end{abstract}

Kata Kunci: modul, guided inquiry, praktikalitas

*Penulis Korespondensi:

Alamat surel: azzanuzullahputri@gmail.com 


\section{PENDAHULUAN}

Perkembangan ilmu pengetahuan serta teknologi memberikan dampak yang besar dalam bidang pendidikan. Perkembangan dalam bidang tersebut juga menyebabkan perkembangan dalam proses pembelajaran. Paradigma yang awalnya pembelajaran berpusat pada guru telah tergantikan dengan proses pembelajaran yang berpusat pada siswa. Dimana siswa yang terlibat aktif dalam menemukan, menggali dan membangun sendiri pengetahuannya. Pembelajaran tidak lagi berpusat pada guru/dosen sebagai satusatunya sumber ilmu. Saat ini guru/dosen lebih berperan sebagai fasilitator yang merancang dan mengarahkan siswa dalam pembelajaran.

Berbagai kemajuan dalam bidang teknologi informasi juga membawa dampak yang besar dalam cara belajar siswa. Salah satunya dalam cara memperoleh informasi mengenai materimateri perkuliahan. Saat ini mahasiswa telah dapat memanfaatkan berbagai sumber belajar yang banyak tersedia, baik itu berupa buku teks maupun sumber informasi secara online dari internet. Akses yang luas terhadap sumber belajar akan sangat membantu mahasiswa dalam pemerolehan informasi mengenai materi yang akan dipelajari.

Pada program studi Pendidikan Biologi Universitas Maritim Raja Ali Haji, proses perkuliahan telah menerapkan sistem student centre dimana mahasiswa diminta menyajikan materi perkuliahan berdasarkan silabus yang telah diberikan. Berdasarkan hasil pengamatan dan penilaian terhadap kegiatan perkuliahan serta hasil penyajian materi mahasiswa, sebagian besar mahasiswa masih banyak menggunakan referensi dari sumber-sumber rujukan yang belum valid. Disamping itu sebagian besar mahasiswa melakukan copy paste tanpa menyadur informasi tersebut terlebih dahulu. Hal ini sangat rentan dan berakibat terhadap berkurangnya sikap kritis mahasiswa terhadap suatu informasi yang diperolehnya.
Matakuliah teknik dan manajemen laboratorium Biologi merupakan salah satu matakuliah wajib bagi mahasiswa prodi Pendidikan biologi. Matakuliah ini akan membekali mahasiswa dengan materi yang berkaitan dengan manajemen laboratorium, teknik-teknik atau cara bekerja di dalam laboratorium, penggunaan alat, pengenalan bahan serta keselamatan kerja di dalam laboratorium. Biologi sebagai bagian dari sains yang memiliki empat tujuan seperti yang diungkapkan Rustaman et al., (2003) antara lain: mengajarkan fakta-fakta biologi, mengembangkan kemampuan, mengajarkan keterampilan dan mendorong sikap yang nyata. Tujuan tersebut dapat dicapai dengan menggunakan sebuah strategi yang tepat dalam membelajarkan Biologi.

Model pembelajaran inquiry merupakan salah satu model pembelajaran yang cocok digunakan dalam pembelajaran sains. Dalam prosesnya, siswa tidak hanya berperan sebagai penerima materi pelajaran dari guru, melainkan mereka berperan untuk menemukan sendiri inti dari materi pelajaran tersebut. Proses pembelajaran inkuiri meliputi lima langkah yaitu: merumuskan masalah, mengajukan hipotesis, mengumpulkan data, menguji hipotesis, dan menarik kesimpulan (Sanjaya, 2010).

Wenning (2011) mengklasifikasikan inquiry menjadi 8 level. Level tersebut ditetapkan berdasarkan sejauh mana fokus kontrol antara peserta didik dan kompleksitas pengalaman intelektual yang diperolehnya selama proses pembelajaran. Level inquiry ini terdiri dari discovery learning, interactive demonstration, inquiry lesson, guided inquiry lab, bounded inquiry lab, free inquiry lab, pure hypothetical inquiry dan yang paling tinggi tingkatnya applied hypothetical inquiry. Masing-masing level inquiry ini memiliki karakteristiknya sendiri.

Disamping itu, hal tersebut juga perlu didukung oleh sarana prasarana, media dan bahan ajar yang dapat membantu mahasiswa 
menjadi lebih mandiri. Hal ini bertujuan agar dapat menuntun mahasiswa untuk menemukan konsep-konsep dalam proses pembelajaran yang diikutinya. Bahan ajar merupakan salah satu sarana pembelajaran dalam bentuk cetak yang disusun secara sistematis, terdapat materi pembelajaran, metode pembelajaran, tujuan pembelajaran, berdasarkan kompetensi, petunjuk kegiatan mandiri, dan memberikan kesempatan kepada mahasiswa untuk menguji diri sendiri melalui latihan (Prastowo, 2012). Modul merupakan salah satu bahan ajar mandiri bagi mahasiswa. Pada modul berisi beberapa kegiatan yang dapat mengaktifkan siswa dalam proses pembelajaran.

Guided inquiry dapat diterapkan pada mahasiswa dalam pembelajaran teknik dan manajemen laboratorium dimana mahasiswa dilatih untuk melakukan inkuiri dalam melakukan teknik-teknik praktikum yang sering dilakukan dalam pembelajaran biologi. Pengembangan dilakukan dengan menggunakan model pengembangan Hannafin dan Peck (1988) yang berorientasi kepada pengembangan produk. Dalam proses pengembangan akan dilakukan uji validasi dan praktikalitas terhadap modul yang dihasilkan. Pada artikel ini akan dibahas bagian praktikalitas dari modul yang telah dikembangkan.

\section{METODE PENELITIAN}

\section{HASIL DAN PEMBAHASAN}

Data mengenai praktikalitas modul didapatkan dari angket respon yang diberikan oleh mahasiswa. Angket respon diberikan pada uji coba terbatas menggunakan modul yang telah dikembangkan. Distribusi frekuensi respon mahasiswa terhadap penggunaan modul dapat dilihat pada tabel di bawah ini.

Tabel 1. Distribusi frekuensi respon mahasiswa terhadap penggunaan modul

\begin{tabular}{cccc}
\hline Kategori & Kategori & & \\
Respon & skor & Frekuensi & $\%$ \\
\hline
\end{tabular}

\begin{tabular}{cccc}
\hline Sangat positif & $56-70$ & 38 & 100 \\
\hline Positif & $42-56$ & 0 & 0 \\
\hline Negatif & $28-42$ & 0 & 0 \\
\hline Sangat negatif & $14-28$ & 0 & 0 \\
\hline
\end{tabular}

Berdasarkan tabel 1 terlihat bahwa sikap tiap responden yaitu mahasiswa terhadap modul yang digunakan seluruhya berada pada kategori respon sangat positif artinya seluruh mahasiswa yaitu yang berjumlah 38 orang memberikan respon yang sangat positif terhadap penggunaan modul berbasis guided inquiry pada matakuliah teknik dan manajemen laboratorium biologi.

Mahasiswa yang mengisi angket respon terhadap penggunaan modul berbasis guided inquiry pada matakuliah teknik dan manajemen laboratorium biologi adalah mahasiswa yang mengikuti ujicoba terbatas terhadap penggunaan modul. Dimana mahasiswa yang menjadi responden adalah mahasiswa yang sedang mengambil matakuliah manajemen dan teknik laboratorium biologi.

Adapun persentase respon pada tiap aspeknya dapat dilihat pada gambar di bawah ini

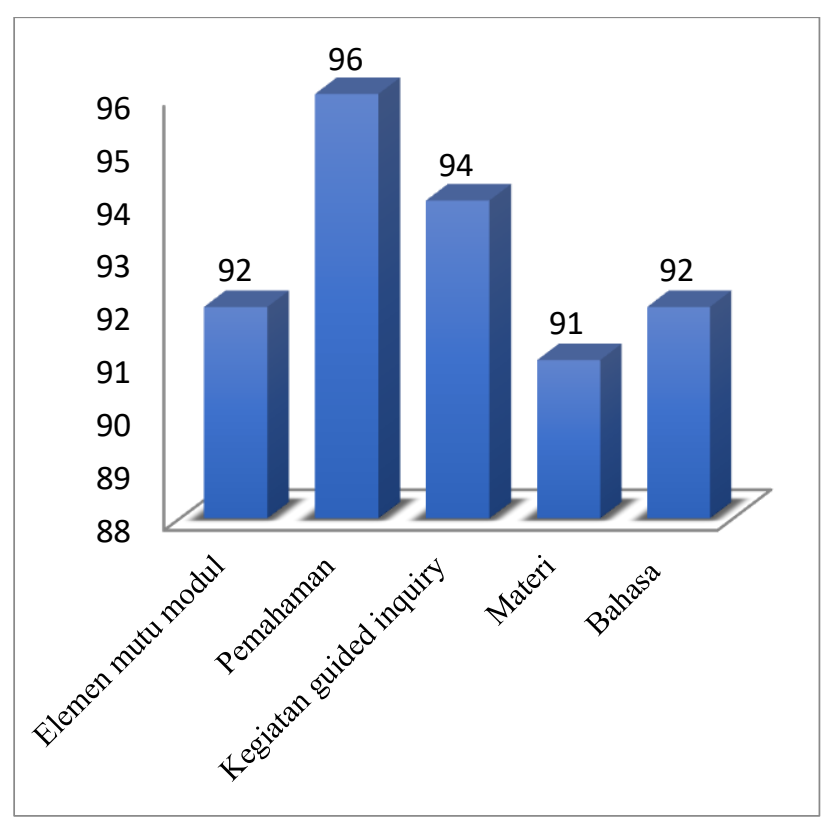




\section{Gambar 1. Hasil angket respon mahasiswa terhadap penggunaan modul}

Gambar 1 menunjukkan hasil respon mahasiswa terhadap modul berbasis guided inquiry yang telah dikembangkan. Masingmasing aspek pada angket respon mahasiswa di dapatkan persentase yang tergolong pada kriteria sangat layak yang artinya praktis untuk digunakan oleh mahasiswa. Rata-rata persentase terhadap seluruh aspek yaitu 93\% dengan kategori sangat layak. Aspek pemahaman mendapatkan persentase respon yang paling tinggi, dimana mahasiswa menganggap bahwa modul yang dikembangkan dapat membantu mereka dalam memahami konsep-konsep pada perkuliahan teknik dan manajemen laboratorium. Sedangkan aspek materi mendapatkan persentase rendah dibandingkan yang lainnya. Mahasiswa menilai bahwa modul yang dikembangkan masih harus diperkaya gambargambar yang lebih banyak lagi untuk lebih memudahkan dalam memahami materi yang disajikan.

Pada aspek kegiatan yang disajikan di dalam modul sebagian besar mahasiswa memberikan penilaian yang tinggi, hal ini dikarenakan mahasiswa sangat senang untuk terlibat aktif dalam perkuliahan. Hal ini menjadi salah satu tujuan dari pengembangan modul berbasis guided inquiry, dimana mahasiswa dilibatkan secara aktif dalam mencari serta menyelidiki konsep-konsep ataupun informasi yang berkaitan dengan materi pada matakuliah teknik dan manajemen laboratorium Biologi.

Guided inquiry sebagai salah satu model pembelajaran yang cocok untuk diterapkan dalam pembelajaran IPA. Hal ini disebabkan karena model pembelajaran ini sesuai dengan hakikat sains itu sendiri dimana salah satunya proses. Mahasiswa dituntut untuk dapat memiliki keterampilan proses untuk dapat melakukan suatu penyelidikan atau pencarian, yang nantinya dapat menghasilkan produkproduk sains itu sendiri. Keterampilan proses ini salah satunya dikembangkan pada proses perkuliahan teknik dan manajemen laboratorium, dimana mahasiswa dibekali pengetahuan mengenai laboratorium, manajemen serta teknik cara kerja di dalam laboratorium biologi.

\section{KESIMPULAN DAN SARAN}

Hasil pengembangan modul berbasis guided inquiry yang telah dilakukan diperoleh data uji praktikalitas modul yang diperoleh menggunakan angket respon mahasiswa. Hasil angket respon diperoleh bahwa seluruh mahasiswa memberikan respon yang sangat positif terhadap modul yang telah dihasilkan. Pada seluruh aspek di dapatkan kategori sangat praktis dengan rata-rata persentase $93 \%$ untuk dapat digunakan pada matakuliah teknik dan manajemen laboratorium biologi oleh mahasiswa.

\section{UCAPAN TERIMAKASIH}

Ucapan terimakasih disampaikan kepada Direktorat Riset dan Pengabdian Masyarakat Direktorat Jenderal Penguatan Riset dan Pengembangan, Kemenristekdikti yang telah memberikan dana Penelitian Dosen Pemula serta juga kepada semua pihak yang telah membantu terlaksananya penelitian ini.

\section{DAFTAR PUSTAKA}

Hannafin, M.J. \& Peck, K.L. (1988). The design, development and evaluation instructional software. New york: Macmillan Publishing Company

Prastowo, Andi. (2012). Panduan Kreatif Membuat Bahan Ajar Inovatif. Yogyakarta: Diva Press.

Rustaman, N.Y., Dirdjosoemarto, S., Yudianto, S.A., Achmad, Y., Subekti, R., Rochintaniawati, D., dan Nurjhani, M. (2003). Common textbook (EdisiRevisi) Strategi Belajar Mengajar Biologi. Bandung: FPMIPA UPI 
Sanjaya, Wina. (2010). Strategi Pembelajaran Berorientasi Standar Proses Pendidikan. Jakarta: Kencana

Wenning, C. J. (2011). The Levels of Inquiry Model of Science Teaching. Journal of Physics Teacher Education Online. 6(2), Summer, pp. 2-9. 